\title{
Callosphecodes, a little-known bee (Hymenoptera, Halictidae, Sphecodes)
}

\author{
Claus Rasmussen', Charles D. Michener ${ }^{2}$ \\ I Department of Biological Sciences, Aarhus University, Ny Munkegade 114, DK-8000 Aarhus C, Denmark \\ 2 Division of Entomology, Natural History Museum and Dept. of Ecology and Evolutionary Biology, 1501 \\ Crestline Drive, University of Kansas, Lawrence, Kansas 66045, USA \\ Corresponding author: Claus Rasmussen (alrunen@yahoo.com)
}

Academic editor: Michael Engel| Received 7 June 2011 | Accepted 4 August 2011 | Published 8 September 2011

Citation: Rasmussen C, Michener CD (2011) Callosphecodes, a little-known bee (Hymenoptera, Halictidae, Sphecodes). ZooKeys 127: 61-68. doi: 10.3897/zookeys.127.1670

\begin{abstract}
Callosphecodes Friese, 1909, a synonym or perhaps subgenus of Sphecodes Latreille, 1804, is known on the basis of one female of Sphecodes ralunensis (Friese, 1909) from New Britain and one female and one male of a similar species, Sphecodes manskii (Rayment, 1935) from northeastern Australia. The male is here described for the first time and the females of the two species are compared for the first time. In spite of considerable collecting, only these three specimens have appeared in over a century. Descriptions and illustrations are provided.
\end{abstract}

\section{Keywords}

Apoidea, Anthophila, Halictinae, Halictini, Sphecodina, Sphecodes, New Britain, Bismarck Archipelago, Australia, taxonomy, cleptoparasite

\section{Introduction}

Even in parts of the world where there has been little investigation of the bee fauna, taxa of bees so distinctive as to have received genus-group names a century or more ago have usually been collected several times so that multiple specimens are now known. Callosphecodes Friese, 1909, however, until now has been known from only two female specimens of different species from localities over $1500 \mathrm{~km}$ apart. A third specimen, a male, is herein reported for the first time. To judge by the lack of pollen manipulating 
and carrying structures in females, this is a cleptoparasitic group. Many cleptoparasites are uncommon, and it seems possible that Callosphecodes is a rare insect, not only in collections but also in the field.

We follow various earlier authors in considering Callosphecodes to be a synonym or possibly a subgenus of Sphecodes Latreille, 1804, which is the most common and widespread genus of cleptoparasitic Halictinae. This cleptoparasitic group was given subtribal status as the Sphecodina in the tribe Halictini (subfamily Halictinae) in the phylogenetic study by Pesenko (2000). Nonetheless, the two species that have been placed in Callosphecodes have a distinctive appearance different from that of the many other species of Sphecodes. Such other species are 4 to $15 \mathrm{~mm}$ in length, usually black with a partly or wholly red metasoma, but males in particular may be entirely black. A female at a host cell destroys the egg of the host and replaces it with her own. Further information on Sphecodes biology can be found in works by Ordway (1964), Eickwort and Eickwort (1972), Torchio (1975), Sick et al. (1994), and summarized by Michener $(2000,2007)$.

\section{History}

Callosphecodes was proposed as a subgenus of Sphecodes by Friese (1909) but in the same paper, in describing the included species, Callosphecodes was treated as a genus. The only species included at that time was Callosphecodes ralunensis Friese (1909), based on a single female presumably from Ralum, New Britain, in the Bismarck Archipelago $\left(04^{\circ} 21^{\prime} \mathrm{S}, 152^{\circ} 17^{\prime} \mathrm{E}\right)$. By error, Friese (1925) indicated that Callosphecodes had been described from Australia in 1912. It was separated from typical Sphecodes by its large size (but it is much smaller than the larger typical Sphecodes) and by the metallic blue black metasoma. Meyer (1920) repeated Friese's description and because of the metallic coloration, suggested that Callosphecodes was close to the neotropical genus Temnosoma Smith (1853). The latter, however, is a very different cleptoparasite of the halictid tribe Augochlorini.

Subsequent views on the position of Callosphecodes have varied from a distinct genus (Friese 1925) to synonymy with Sphecodes (Michener 1944, 1978, 2000, 2007) or a subgenus of Sphecodes (Michener, 1965). These viewpoints were not based on additional information about the type species, for the type and only known specimen of $S$. ralunensis was not reexamined. After inquiring about the specimen from personnel of the Magyar Természettudományi Múzeum, Budapest, and the Museum für Naturkunde der Humboldt-Universität, Berlin, Michener (2000, 2007) concluded that the specimen was probably lost. It has been found, however, in good condition in the Berlin museum and was borrowed for study by C.R.; all the labels were illustrated by Rasmussen and Ascher (2008, fig. 8).

A second specimen of Callosphecodes was described as Mellitidia manskii (Rayment 1935) on the basis of a single female collected in 1934 by Martin J. Manski at Cairns $\left(16^{\circ} 55^{\prime} \mathrm{S}, 145^{\circ} 46^{\prime} \mathrm{E}\right)$ in northern Queensland, Australia. It is not clear why it 
was placed by Rayment in a nomiine genus whose females, unlike cleptoparasites, have a strong scopa. Placement of this species in the genus Sphecodes was by Michener (1965), who saw the type, but association with Callosphecodes was not certain since the type of $S$. ralunensis was not then available. The holotype of $S$. manskii is in the Australian National Insect Collection, Canberra, and has been borrowed by C.R. for direct comparison with that of $S$. ralunensis. They are very similar, certainly both constituting the Callosphecodes group. Michener (1978) and Cardale (1993) included S. manskii not merely in Sphecodes but in the subgenus Sphecodes s.str.

Also, in the Australian National Insect Collection, was found a male, judged on the basis of similarity to the female and on geography, to be $S$. manskii. It was collected in 1980 by Josephine C. Cardale in Mount Webb National Park (15.045S, 145.07E), Queensland, Australia, about $100 \mathrm{~km}$ from Cairns, the type locality for S. manskii.

When reviewing the cleptoparasitic groups of Halictidae, Michener (1978) differentiated the genera such as Eupetersia Blüthgen, 1928, from Sphecodes; see also Michener (2000, 2007). It is apparent that Callosphecodes, contrary to earlier suggestions (Michener, 1978), is not the same as any such genera but, as we have indicated above, does not differ appreciably from ordinary Sphecodes. The principle difference mentioned in the literature between such Sphecodes and Callosphecodes is the metallic blue, greenish or purplish black metasoma of the latter, independently mentioned by both Friese and Rayment in describing the two species. Yet, at least at present, the metallic tints of the specimens are extremely feeble, scarcely detectable, the metasoma being essentially black.

\section{Description}

The following descriptive comments, largely following the pattern of Michener's (1978) account of Sphecodes, are based on the three known specimens of the Callosphecodes group, that is Sphecodes ralunensis and manskii (Figs 1, 6 and 13). The description of Sphecodes by Michener (1978) indicates the variation in many characters among the species of the genus. Notes below on the genus Eupetersia are inserted to counter the suggestion mentioned in Michener $(2000,2007)$ that Callosphecodes might be a senior synonym of Eupetersia.

Both sexes: Black, metasomal terga with feeble bluish, purplish, or blue green metallic tints (Figs 2 and 7); wings strongly infuscated (fig. 12). Punctation of head and thorax coarse (fig. 4; moderately fine in Eupetersia); punctures of mesoscutum, especially posteriorly, widely separated (by much more than puncture diameter) by shining surface (fig. 5). Head in facial view much wider than long, clypeus more than twice as wide as long (Figs 3 and 10). Eyes hairless. Hairs of antennal flagellum all very short. Preoccipital carina strong and distinct. Posterior end of hypostomal carina with tooth (fig. 11). Pronotum with horizontal surface of collar almost absent medially, forming lateral angle below which a vertical ridge extends downward; vertical ridge approaching or merging with a more laterally directed ridge that extends toward coxal base; another carina from lateral angle extends across posterior lobe of pronotum. Anterior 

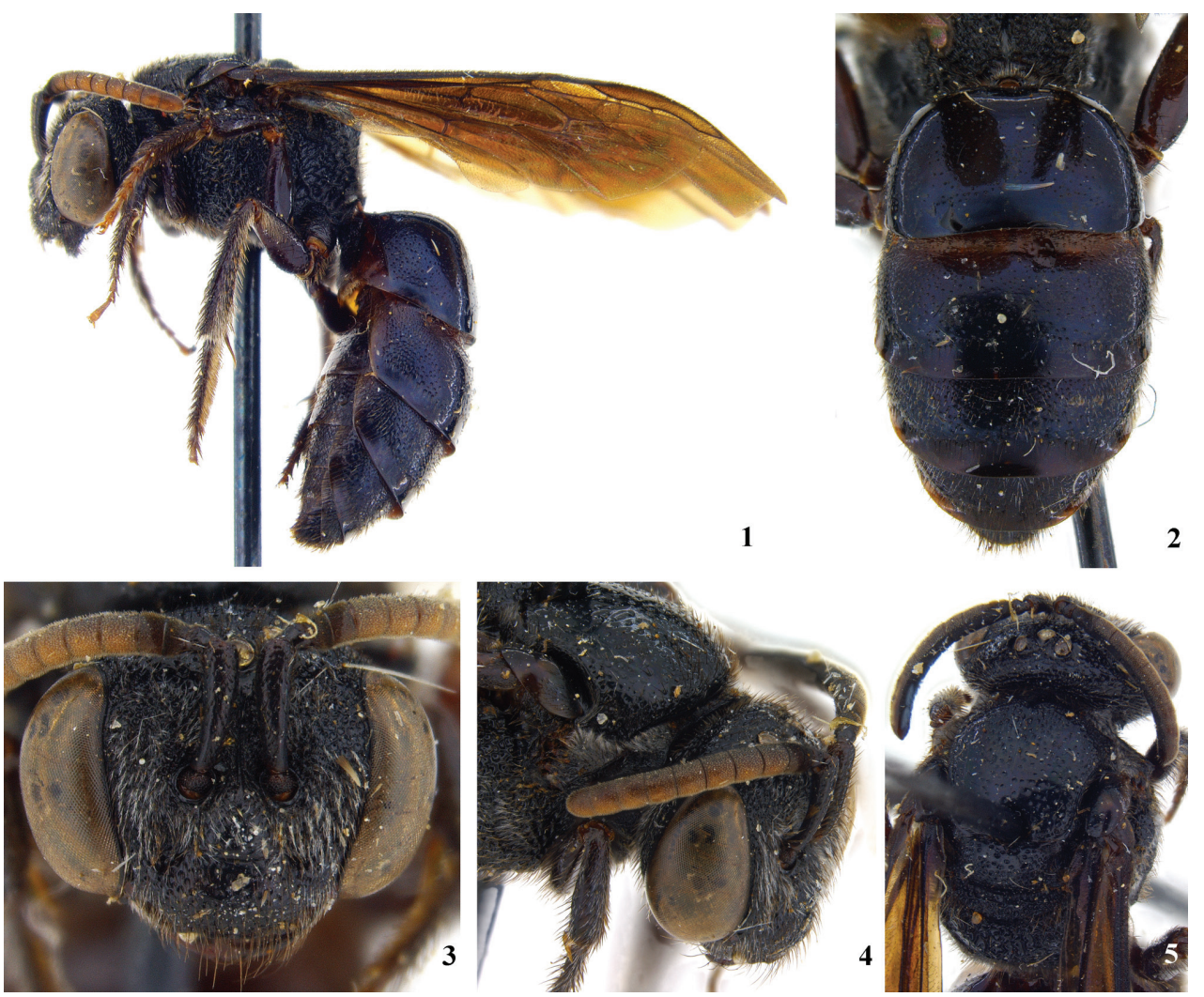

Figure I-5. Holotype female of Sphecodes ralunensis: I lateral habitus $\mathbf{2}$ metasoma $\mathbf{3}$ facial aspect $\mathbf{4}$ dorsolateral aspect of head and pronotum $\mathbf{5}$ dorsal aspect of mesosoma and head.

extremity of mesoscutum convex. Scutellum gently biconvex because of feeble longitudinal median depression. Propodeum with dorsal area strongly areolate, about as long as scutellum, area broadly rounded posteriorly (fig. 9); posterior and lateral surfaces of propodeum with few short plumose hairs in addition to longer hairs. Wings with hairs rather long and dense throughout (as in Eupetersia); stigma moderate; marginal cell pointed at apex; free part of marginal cell beyond submarginal cells longer than part subtended by submarginal cells, which part extends well beyond apex of stigma. Second and third submarginal cells each receiving a recurrent vein (fig. 12). First metasomal tergum broader than long. Second tergum in lateral view with base somewhat 

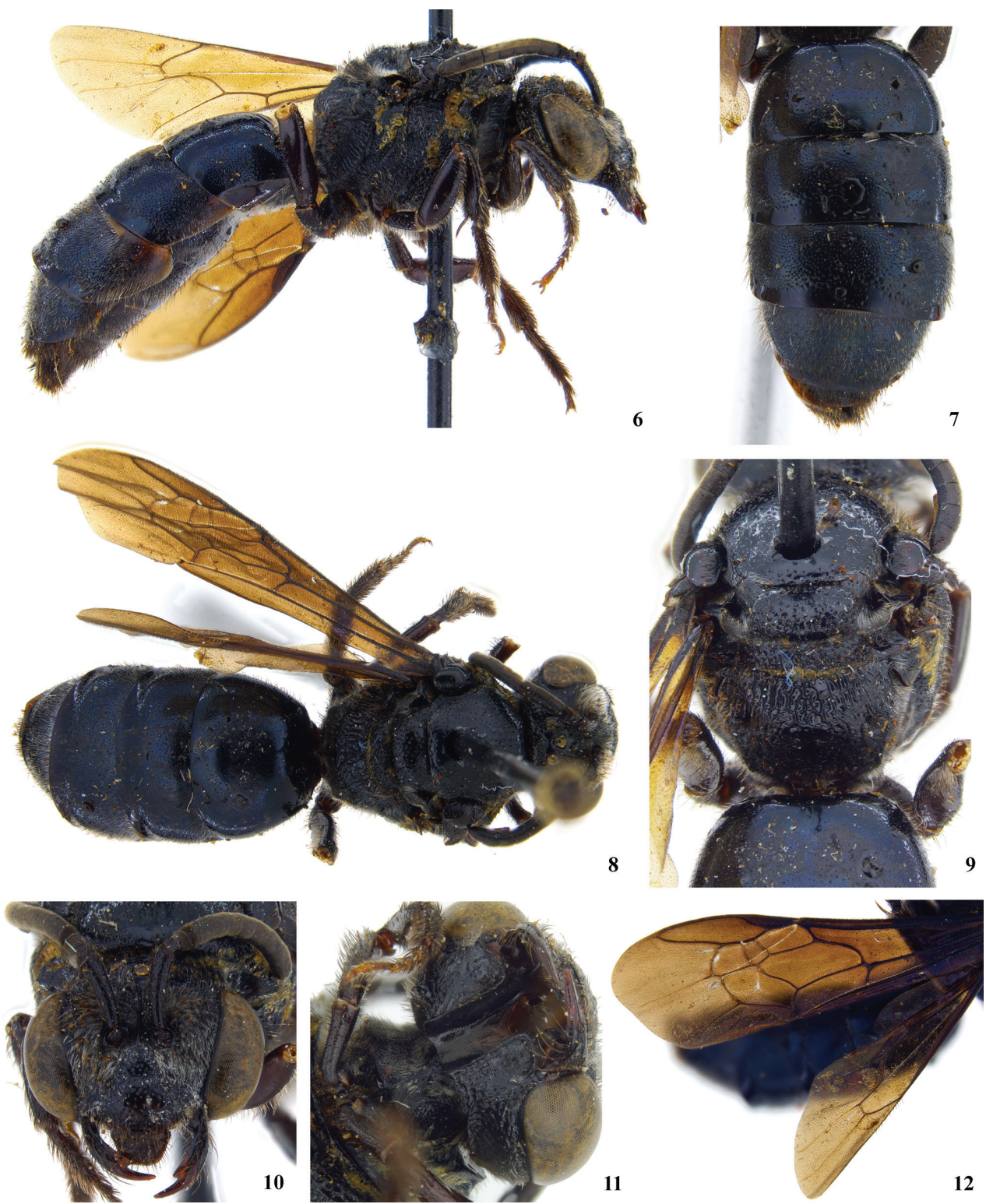

Figure 6-12. Holotype female of Sphecodes manskii: $\mathbf{6}$ lateral habitus $\mathbf{7}$ metasoma 8 dorsal habitus 9 mesosoma including propodeum $\mathbf{I O}$ facial aspect II hypostomal carina with tooth at posterior end 12 forewing pattern. 

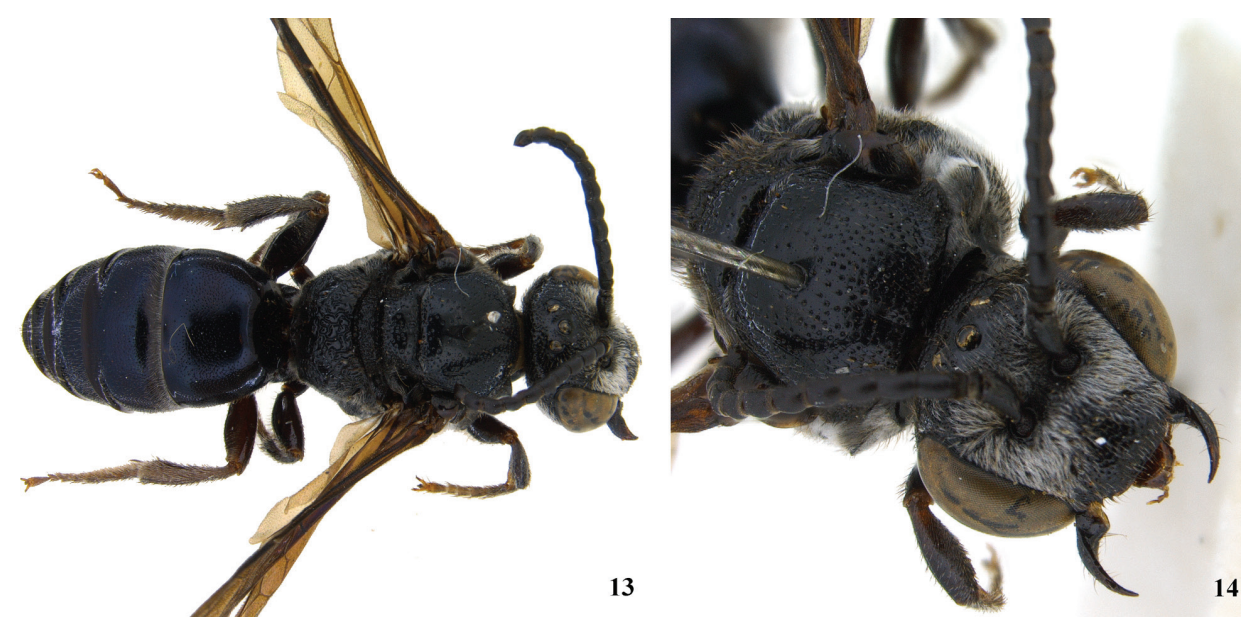

Figure 13-I4. Male of Sphecodes manskii: I 3 dorsal habitus; 14 dorsolateral aspect of head and pronotum.

depressed forming weak constriction between first and second terga. Posterior margins of terga $2-4$ broadly depressed, hairless, impunctate.

Female: Mandible with large subapical tooth (fig. 10; unlike Eupetersia). Labrum with broad, flat apical process about two thirds as broad as long. Legs robust, hind femur about three times as long as broad; basitibial plate elevated; long hairs on outer side of hind tibia plumose; hind tibial spine finely serrate. Fifth metasomal tergum, unlike preceding terga, with apical margin fringed except middle part of margin which has smooth, hairless area in front of fringeless part of margin. Pygidial plate broader than in Eupetersia.

Male: Antennae longer than those of female, flagellum thickened (fig. 13; unlike Eupetersia), somewhat crenulate, first flagellar segment broader than long, second longer than first, both first and second shorter than subsequent segments but not very short as in Eupetersia. Labrum not visible on specimen. Second hind tarsal segment longer than third, base broader than base of third. Gonocoxite finely striate, without margined depression as in Eupetersia. Gonocoxite with basal setose lobe (Figs 15 and 16).

Specific differences: The holotypes (both females) are very similar and we have no way of knowing whether the differences between them are specific differences or indicate variation within a species. The differences (observed by CR) are as follows: Lateral margin of propodeum (immediately below metanotum) in S. ralunensis largely areolate, in S. manskii widely strigulate and less areolate. Gena of $S$. ralunensis sparsely covered with plumose, light colored setae, in $S$. manskii densely covered with white setae. Flagellum in S. ralunensis ferruginous (fig. 3), in S. manskii dark brown (fig. 10). Measurements are as follows for the $S$. ralunensis holotype female: Total body length about $10 \mathrm{~mm}$; forewing length (including tegula) $8.8 \mathrm{~mm}$; head width $3.1 \mathrm{~mm}$; head length (anterior margin of clypeus to summit of vertex) $2.5 \mathrm{~mm}$; mesoscutum width 2.1 ; mesoscutum length 2.0 $\mathrm{mm}$. The $S$. manskii holotype female: Total body length about $12 \mathrm{~mm}$; forewing length (including tegula) $9.5 \mathrm{~mm}$; head width $3.2 \mathrm{~mm}$; head length (anterior margin of clypeus to summit of vertex) $2.5 \mathrm{~mm}$; mesoscutum width 2.3 ; mesoscutum length $2.0 \mathrm{~mm}$. 


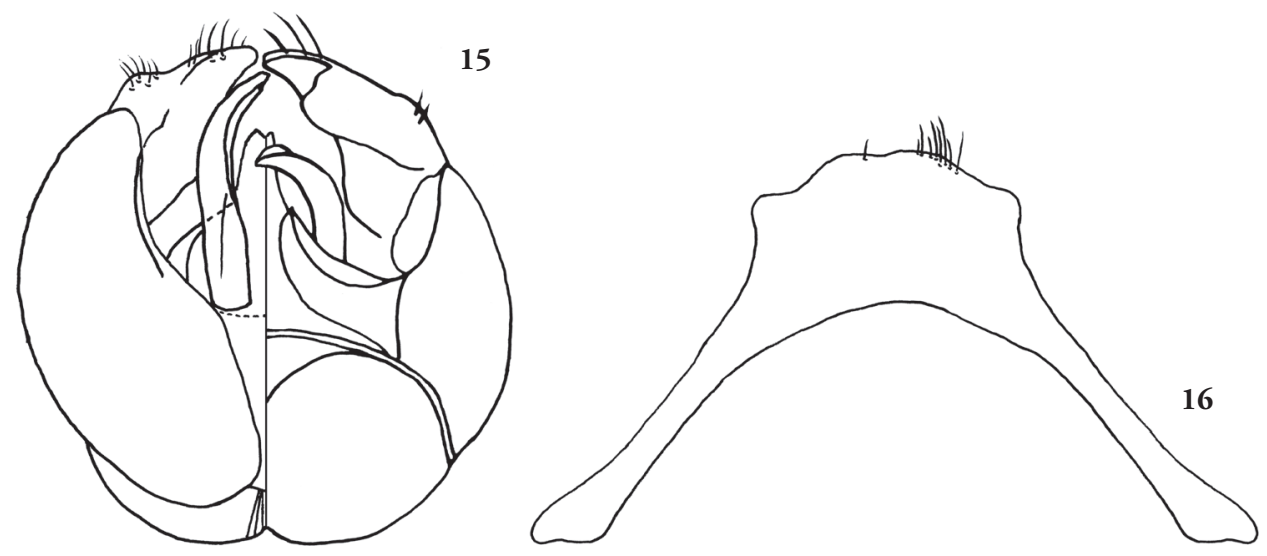

Figure 15-16. Male genitalia of Sphecodes manskii: 15 Dorsalventral view of genitalia; $167^{\text {th }}$ metasomal sternum.

Male S. manskii: Total body length about $11 \mathrm{~mm}$; forewing length (including tegula) 8.1 $\mathrm{mm}$; head width $2.9 \mathrm{~mm}$; head length (anterior margin of clypeus to summit of vertex) $2.5 \mathrm{~mm}$; mesoscutum width 2.3 ; mesoscutum length $2.2 \mathrm{~mm}$.

\section{Acknowledgements}

We are very thankful to the curators for loan of the specimens: Frank Koch of the Museum für Naturkunde der Humboldt-Universität, Berlin, and Nicole Fisher of the Australian National Insect Collection, Canberra. Also to Carlsberg Foundation for support (C.R.) and Lars Vilhelmsen and Verner Michelsen of the Natural History Museum of Denmark for providing access to the imaging system.

\section{References}

Blüthgen PAV (1928) 2. Beitrag zur Kenntnis der äthiopischen Halictinae (Hym. Apid.). I. Die Gattung Eupetersia nov. gen. Deutsche Entomologische Zeitschrift 1928: 49-72.

Cardale JC (1993) Hymenoptera: Apoidea. In: Houston WWK, Maynard GV (Eds) Zoological catalogue of Australia, Vol. 10. AGPS, Canberra, $x+406$ pp.

Eickwort GC, Eickwort KR (1972) Aspects of the biology of Costa Rican halictine bees, III. Sphecodes kathleenae, a social cleptoparasite of Dialictus umbripennis (Hymenoptera: Halictidae). Journal of the Kansas Entomological Society 45: 529-541.

Friese H (1909) Die Bienenfauna von Neu-Guinea. Annales Historico-Naturales Musei Nationalis Hungarici (Természettudományi Múzeum évkönyve) 7: 179-288.

Friese H (1912) Zur Bienenfauna von Neu-Guinea und Oceanien. Übersicht des von den Herren Dahl, Finsch, Krämer, Moszkowski, Neuhaus, Schoede und L. Schultze in den 
letzten Jahren dem Zoologischen Museum in Berlin überwiesenen Forschungsmaterials. Mitteilungen aus dem Zoologischen Museum in Berlin 6: 91-96.

Friese H (1925) Über die Urbienengattung Temnosoma Sm. Zoologische Jahrbücher, Abteilung für Systematik, Geographie und Biologie der Tiere 49: 534-536.

Latreille PA (1804). Tableau méthodique des insectes. Classe huitième. Insectes, Insecta. In: Latreille PA (Ed) Nouveau dictionnaire d'histoire naturelle, appliquée aux arts, principalement à l'agriculture et à l'économie rurale et domestique: par une société de naturalistes et d'agriculteurs: avec des figures tirées des trois règnes de la nature, Vol. 24. Déterville, Paris, 129-200.

Meyer R (1920) Apidae - Sphecodinae. Archiv für Naturgeschichte. Abteilung A 85(1-2): 79-160, 161-242.

Michener CD (1944) Comparative external morphology, phylogeny, and a classification of the bees. Bulletin of the American Museum of Natural History 82: 151-326.

Michener CD (1965) A classification of the bees of the Australian and south Pacific regions. Bulletin of the American Museum of Natural History 130: 1-362.

Michener CD (1978) The parasitic groups of Halictidae (Hymenoptera, Apoidea). University of Kansas Science Bulletin 51: 291-339.

Michener CD (2000) The bees of the world. Johns Hopkins University Press, Baltimore, xiv+[1]+913 pp.

Michener CD (2007) The bees of the world, second edition. Johns Hopkins University Press, Baltimore, xvi+953 pp.

Ordway E (1964) Sphecodes pimpinellae and other enemies of Augochlorella (Hymenoptera: Halictidae). Journal of the Kansas Entomological Society 37: 139-152.

Pesenko YA (2000(“1999”)) Phylogeny and classification of the family Halictidae revised (Hymenoptera: Apoidea). Journal of the Kansas Entomological Society 72: 104-123.

Rasmussen C, Ascher JS (2008) Heinrich Friese (1860-1948): Names proposed and notes on a pioneer melittologist (Hymenoptera, Anthophila). Zootaxa 1833: 1-118.

Rayment PT (1935) A cluster of bees; sixty essays on the life-histories of Australian bees, with specific descriptions of over 100 new species, and an introduction by E.F. Phillips. Endeavour, Sydney, $752 \mathrm{pp}$.

Sick M, Ayasse M, Tengö J, Engels W, Lübke G, Francke W (1994) Host-parasite relationships in six species of Sphecodes bees and their halictid hosts: Nest intrusion, intranidal behavior, and Dufour's gland volatiles. Journal of Insect Behavior 7: 101-117.

Smith F (1853) Catalogue of the Hymenopterous insects in the collection of the British Museum. Part I, Andrenidæ and Apidæ. British Museum (Natural History), London, 266 pp.

Torchio PF (1975) The biology of Perdita nuda and descriptions of its immature forms and those of its Sphecodes parasite (Hymenoptera: Apoidea). Journal of the Kansas Entomological Society 48: 257-279. 